\title{
Recent Monetary Policy in the U.S.: Risk Management of Asset Bubbles
}

Anastasios G. Malliaris

Loyola University Chicago, tmallia@luc.edu

Marc D. Hayford

Loyola University Chicago, mhayfor@luc.edu

Follow this and additional works at: https://ecommons.luc.edu/business_facpubs

Part of the Business Commons

\section{Author Manuscript}

This is a pre-publication author manuscript of the final, published article.

\section{Recommended Citation}

Malliaris, Anastasios G. and Hayford, Marc D.. Recent Monetary Policy in the U.S.: Risk Management of Asset Bubbles. The Journal of Economic Asymmetries, 2, 1: 25-39, 2005. Retrieved from Loyola eCommons, School of Business: Faculty Publications and Other Works, http://dx.doi.org/10.1016/ j.jeca.2005.01.002

This Article is brought to you for free and open access by the Faculty Publications and Other Works by Department at Loyola eCommons. It has been accepted for inclusion in School of Business: Faculty Publications and Other Works by an authorized administrator of Loyola eCommons. For more information, please contact ecommons@luc.edu.

\section{(c) $($ () $\ominus$}

This work is licensed under a Creative Commons Attribution-Noncommercial-No Derivative Works 3.0 License. (C) Elsevier B. V. 2005 


\title{
Recent Monetary Policy in the U.S.: Risk Management of Asset Bubbles
}

\author{
Marc D. Hayford \\ Loyola University Chicago \\ A.G. Malliaris ${ }^{1}$ \\ Loyola University Chicago
}

\begin{abstract}
Recently Chairman Greenspan (2003 and 2004) has discussed a risk management approach to the implementation of monetary policy. This paper explores the economic environment of the 1990s and the policy dilemmas the Fed faced given the stock boom from the mid to late 1990s to after the bust in 2000-2001. Drawing on Greenspan's comments about conducting monetary policy in the real world of risk and uncertainty, the paper assesses why US monetary policy was neutral with respect to the stock market boom.
\end{abstract}

JEL Classification: E52, E58, G18

Keywords: Monetary policy, stock market, risk management

\section{Introduction}

In a fascinating talk given at the 2004 Meetings of the American Economic Association, Alan Greenspan (2004, also see 2003) reflected on the implementation of monetary policy in the real world of risk and uncertainty. With Greenspan's term as Chairman of the Federal Reserve Board coming to an end in January 2006, one might wonder if these comments were meant in part as advice to future chairs of the Fed. In this paper we use the policy making framework Greenspan laid out in his talk to try to develop a better understanding of what choices and dilemmas monetary policy makers faced during the stock boom in the mid to late 1990s and the bust in 2000.

Greenspan discusses monetary policy as an exercise in risk and uncertainty management. A monetary policy maker considers the possible future events that may occur due to economic shocks and changes in economic policy. In a world of risk, a well defined probability can be assigned to each event, with the probability being determined by the frequency of such events in the past. The choice of the optimal policy in this case can be thought of as the solution to minimizing a loss function with respect to a policy instrument, such as the Federal funds rate, subject to 
constraints that describe the macroeconomy (see for example Svensson (2003)). However Greenspan argues that the world that monetary policy makers actually live has large elements of "Knightian" uncertainty rather than just risk. That is, while it is often the case that a set of future possible events can be envisioned it is less often the case that objective probabilities can be assigned to such events. Often academic economists take the view that risk and uncertainty are equivalent, so long as all possible future events are assigned at least subjective probabilities. However the choice of the subjective probabilities is just that: subjective.

As Greenspan argues, while monetary policy makers may consider the solutions to well defined optimization problems in setting policy, they also use a large element of judgment that sometimes is hard to quantify even if the idea of subjective probabilities is mentioned in policy deliberations. For example, in the February 1994 FOMC meeting the debate was whether to increase the Federal funds rate 25 or 50 basis points. Greenspan favored a 25 basis point increase while some on the committee were initially leaning toward a 50 basis point increase. Greenspan argued that "Well, I've been around a long time watching markets behave and I will tell you that if we do 50 basis points today, we have a very high probability of cracking these markets" (see FOMC transcripts February 3 and 4 1994). Hayford and Malliaris (2001) discuss this event more completely and it seems clear that Greenspan's view was based on his judgment or gut feel for the markets. It reflects the respect that the other FOMC members had for Greenspan's judgment that FOMC choose to go with a 25 basis point increase in the funds rate.

In a risk and uncertainty management approach to the implementation of policy, Greenspan argues that low objective or subjective probability events with a high potential loss have to be considered and responded to. Such possible future events, are typically not captured by simple rules that have been suggested for monetary policy, such as targeting monetary aggregates or more recently the Taylor rule for the Federal funds rate. Hence Greenspan argues that, while monetary policy can be informed by econometric models and monetary policy rules, ultimately anyone who becomes a central banker, comes around to the position that appropriate monetary policy involves a significant amount of discretion and subjective judgment.

Next we explore the economic environment of the 1990s and the policy dilemmas the Fed faced given the stock boom from the mid to late 1990s to after the bust in 2000-2001. We will argue that the Fed faced considerable uncertainty at least prior to 2000 about both what was happening in the US economy and what the appropriate policy response was.

\section{The U.S. Economy in the 1990s}

It is always the case that the ever-changing nature of the U.S. economy presents continuous challenges to both economic agents and policy makers. During the 1990s several major events contributed both as external shocks to, as well as structural changes in, the economy and financial markets in the U.S. For example, the end of the cold war with the collapse of the former Soviet Union at the end of the 1980s, the 
growth of globalization and in particular the economic opening of China, the taming of inflation, the rapid technological innovations and scientific advances in fiber optics, telecommunications, computing, information management and biomedicine, among other factors, all caused important structural changes in the U.S. economy that potentially changed the quantitative behavior of the economy relative to the past. These factors contributed to the length and strength of economic prosperity which began in the second quarter of 1991 and ended at the end of the first quarter of 2001. During this 10-year economic boom, long-term interest rates decreased gradually, labor productivity increased and inflation declined.

Figure 1 about here

Figure 1 presents data on key variables for setting monetary policy in the 1990s. The data are quarterly and except for the stock market data are from the FRED ${ }^{\circledR}$ database maintained by the Federal Reserve Bank of St. Louis (http://www.stls.frb.org/fred/). The S\&P 500 composite index and the P/E ratio are from the Standard and Poor's Security Price Index Record. The top two graphs show the real GDP gap, as measured using the CBO measure of the potential real GDP as of April 2005 and the unemployment rate. These two graphs measure business cycle fluctuations in the 1990s. The bottom left graph shows inflation as measured by the growth rate of the consumer expenditure price index.

The middle two graphs show the stock market as measured by the S\&P 500 composite index and the P/E ratio. In the 1990s the stock market boomed. The S\&P 500 Index increased from 360 in July of 1990 to a peak of 1473 in July 2000, that is, the stock market grew at an average rate of $15.1 \%$ per year during this decade. This boom presented a challenge to monetary policymakers. In 1996, Greenspan made his how famous statement about the stock market potentially being driven by "irrational exuberance" stating that economic agents were excessively optimistic with a greater than average willingness to take risks thus causing asset prices to grow faster than economic fundamentals. Later in the decade Greenspan seemed to switch to a "new economy hypothesis" claiming that increased technological innovations had permanently increased labor productivity and real profit growth thus justifying the higher asset prices.

The bottom right graph in figure 1 shows the effective Federal funds rate. One way to indicate the stance of monetary policy is to consider the value of the Federal funds rate relative to the "neutral Federal funds rate". The theoretical foundation for this approach to monetary policy is developed by Woodford (2003) and is discussed in a recent speech by Fed Vice Chairman Ferguson (2004). The neutral funds rate is the sum of the natural real interest rate and the Fed's implicit target for inflation. The natural real interest rate, typically estimated to be around $2 \%$, is the real interest when real GDP equals potential real GDP. The Fed's implicit inflation target is thought to be about $2 \%$ resulting in a neutral Federal funds rate of $4 \%$. A Federal 
funds rate above neutral implies a tight monetary policy while below neutral implies monetary ease.

Since the actual neutral Federal funds rate is not known precisely, in the graph for the effective Federal funds rate we have indicated a tight monetary policy for a Federal funds rate at or above $5 \%$ and easy when it is at or below $3 \%$. Using this approach, starting in 1990 monetary policy was tight but moving toward ease as the economy moved into a recession in 1990-91. By 1992 to 1993 monetary policy was neutral to border line easy. At the beginning of 1994 monetary policy moves from easy into the tight range by the end of 1994 and remains tight until 1998. There is a slight ease in 1998 due to the Russian debt crisis, after which monetary policy tightens to $6.5 \%$ at the end of 2000. Beginning in 2001 the Fed dramatically shifts from tight, to neutral to easy by the end of 2001. By 2003, the Federal funds rate is 550 basis points below its peak level in 2000. Since 2004 the Fed has been moving the funds rate back to neutral.

The relevant question for this paper is how much of these movements in the Federal funds rate were in response to inflation and the economic activity and how much was due to the Fed responding directly to a potential bubble in the stock market? Without any hard evidence to prove or disprove the existence of a bubble or determine its magnitude, the Fed and the rest of the world faced uncertainty about whether there was a bubble or not. In addition, as discussed below, economists are uncertain about what the appropriate monetary policy response should be to an on going stock price bubble.

Using the risk and uncertainty management framework, we can think of the Fed considering two possible events: 1) the stock market boom was a bubble, i.e. the "irrational exuberance hypothesis" or 2) the booms was being driven by fundamentals, i.e. the "new economy hypothesis". If the new economy hypothesis was true, and we can imagine monetary policy makers assigning their subjective probabilities to that event, the appropriate response of monetary policy was to stand back and enjoy the prosperity while keeping an eye on the usual variables, for example inflation and the real GDP gap. If the irrational exuberance hypothesis was true, then the Fed faced additional uncertainty about what the appropriate response of monetary policy should be. The Fed faced two policy choices which we call: (1) "asymmetric monetary policy response" and (2) the "symmetric monetary response" to the bubble.

Hayford and Malliaris (2001, 2004a, 2005) present an analysis of the Fed's transcripts and also give econometric evidence that suggest that the Fed accommodated the stock market bubble. They report estimates of Taylor type rules for monetary policy during this period including the $\mathrm{P} / \mathrm{E}$ ratio as a measure of stock market valuation and find that movements in the Federal funds rate were due primarily to changes in inflation and unemployment. Rather than trying to dampen the stock market boom, Hayford and Mallairis argue that at best monetary policy was neutral with respect to the stock market boom or perhaps accommodated the boom. 
The stock market peaked in the spring of 2000. The Fed responded in January 2001 by lowering the Federal funds rate aggressively to reduce the impact of declining asset wealth and falling investment spending on aggregate demand. Hence the Fed ended up following an asymmetric monetary policy response to the stock market bubble. Ex post both Fed Chairman Greenspan (2002) and Governor Bernanke (2002) have defended the Fed's accommodation of the asset bubble by arguing that there is no low-risk, low-cost incremental monetary tightening that can reliably deflate a bubble.

The response of the Greenspan Fed to the stock market bubble of the 1990s is similar to how other central banks have responded to bubbles. Greenspan (1999) suggests that this typical asymmetric response of central banks is due to an asymmetry in financial markets: “... central banks do not respond to gradually declining asset prices. We do not respond to gradually rising asset prices. We do respond to sharply reduced asset prices, which will create a seizing up of liquidity in the system. But you almost never have the type of 180-degree version of seizing up on the up side. If indeed, such an event occurred I think we would respond to it. The actuality is that it almost never occurs, so it appears as though we are asymmetric when, indeed, we are not. The markets are asymmetric; we are not”.

An overview of the literature on asset bubbles presented in Hunter, Kaufman and Pomerleano (2003) suggest that central banks have followed an asymmetric monetary policy response to a bubble more often than not. In other words, monetary policy makers have not typically taken the risk of bursting a bubble since doing so may cause financial and economic instability. The only support the symmetric monetary policy response to bubbles receives is at the early stages of the emergence of the bubble if the economy overheats and inflation increases. However, one cannot claim in such a scenario that the central bank is responding to a bubble.

The rest of the paper conjectures on why US monetary policy was neutral with respect to the stock market boom. Our analysis draws on Greenspan's comments about conducting monetary policy in the real world of risk and uncertainty.

\section{Assessing whether a bubble existed}

In mid to late-1990s some economists considered the question of how should monetary policy react to a stock market bubble as meaningless because there is little agreement on how to recognize a bubble ex ante. The theoretical literature defines a bubble as the difference between the actual market price and the fundamental price. However if the fundamental price cannot be objectively computed, then one can only talk about the existence and the magnitude of the bubble in terms of uncertainty with the consequent subjective probabilities.

One common approach to accessing the existence of a bubble is to compare the current price earnings ratio with the historic average. The mean of the S\&P 500 $\mathrm{P} / \mathrm{E}$ ratio for the post WWII period up until the 1990s is approximately 14. As shown in figure 1 , for the entire period the P/E ratio is higher than 14 , which suggests that 
perhaps the stock market was over-valued. Hence using the level of the P/E ratio to assess stock market valuation, the market was clearly overvalued by the mid 1990s, relative to historic levels. Presumably this information increased the subjective probability that monetary policy makers assigned to the event that there was indeed a stock market bubble.

Shiller (1989) and, more recently Salge (1997), offer an extensive review of the literature on market volatility and discuss both the theoretical and empirical issues associated with bubbles. At the risk of oversimplification, one finding of this literature is that bubbles are easier to identify ex post rather than ex ante. For example, it is difficult to find economists who would argue today that the stock market increase in Japan in the late 1980s or the Nasdaq increase in the late 1990s reflected only fundamentals. The fact that in both cases these markets declined significantly is ex post evidence of the existence of a bubble, yet there was no consensus among economists prior to its dramatic collapse that a bubble was present in these two markets.

In the 1990s the Fed could look to the bubble experiences in other countries and historical periods. Asset price bubbles have been a recurring event in capitalist economies since the invention of financial markets (see Kindelberger (1989)). Two examples of a central bank attempting to pop a stock market bubble are the United States in the 1920s and Japan in the 1980s. As is well known the Japanese stock market grew rather rapidly during the 1980s. When Japanese monetary policy chose to increase interest rates to dampen bubbles in the stock market and the real estate markets, eventually both markets collapsed along with the real economy. However the experience of Japan had with an apparent bubble in the 1980s and its collapse in 1989 was thought to offer less insight for the United States since the asset bubble in Japan involved both the stock market and the real estate market and this was not the case in the U.S..

The U.S. stock boom in the 1920s offers another historical example of a central bank attempting to stop an apparent stock market bubble. Bordo and Wheelock (2004) explore the response of monetary policy to stock market bubbles and find that policy makers both during the 1920s and 1990s paid great attention to finding an appropriate response to bubbles. Hayford and Malliaris (2004b) discuss U.S. monetary policy during the late 1920s and argue while monetary policy in 1928 was tightened to try to dampen stock market speculation the stock market continued to boom. It was only after the contraction in August 1929 that the Great Crash of October 1929 occurred. Hence the examples of the US in the 1920s and Japan in the 1980s do not provide optimistic support for having central banks attempt to dampen or pop apparent bubbles.

Another approach is to look to historical episodes of bubbles to determine the necessary conditions for bubbles to occur. This information can then be used to access the probability that an economy is currently experiencing a bubble. Bordo and Wheelock (2004) offer a detailed discussion of the role of monetary policy during periods of stock market booms and busts. They show that in the U.S. over the past 
two centuries, stock market bubbles have emerged in a variety of macroeconomic conditions. However, certain special characteristics appear to encourage and promote bubbles. Key among these certain macroeconomic variables are (1) rapid growth in labor productivity due to technological innovations, (2) growth in the money supply reflecting either a passive accommodation by the central bank due to expanding bank credit or an easy monetary policy by design, and (3) low inflation and therefore relatively low nominal interest rates. Kindelberger (1989) lays out a similar set of initial conditions for an asset bubble to develop.

One can argue that all these conditions existed in the 1990s, in particular a new technological innovation and low inflation. As Greenspan (2004) later put it "perhaps the greatest irony of the past decade is that the gradually unfolding success against inflation may well have contributed to the stock price bubble of the latter part of the 1990s". The environment of low inflation and low interest rates, high labor productivity and major technological advances have all acted as preconditions for the occurrence of above normal stock market returns. Further this contributed to the formation of optimistic investor expectations and without any action by the central bank to moderate these expectations, moral hazard took root and fed the bubble.

In summary, in December 1996, Greenspan suggested that maybe there was a bubble in the stock market. However bubbles are hard to identify ex ante. As the stock market continued to boom through the rest of the 1990s and the P/E ratio rose to even higher heights, Greenspan's speeches and testimonies seemed to indicate a switch to the "new economy hypothesis". However many economists and analysts expressed doubts about whether the stock price boom was being driven by fundamentals.

\section{How should a central bank respond to a bubble?}

A large number of papers address the question of how a central bank should respond to a stock price bubble. As mentioned above there are two competing hypothesis: asymmetric monetary policy response and the symmetric monetary response to asset bubbles.

Bernanke and Gertler (1999, 2001) argue for an asymmetric monetary policy response to asset price bubbles, that is, a central bank dedicated to a policy of flexible inflation targeting should pay little attention to asset price inflation because setting interest rates to achieve an inflation target will also stabilize asset prices. The authors (1999, p.18) state that "[t]rying to stabilize asset prices per se is problematic for a variety of reasons, not the least of which is that it is nearly impossible to know for sure whether a given change in asset values results from fundamental factors, non-fundamental factors, or both”. The sufficiency of targeting inflation can be argued as follows. Keeping both current and expected inflation at a constant level is equivalent to maintaining output at its natural level. The existence of a bubble can either cause no change in aggregate demand or cause it to increase because of the wealth effect or some other reason. In either case, the monetary rule of inflation targeting guides the central bank to act appropriately, either by doing nothing in the 
case the bubble causes no change in aggregate demand or by tightening in the case the bubble increases aggregate demand via the wealth effect. Hence, according to Bernanke and Gertler, the existence of a bubble should not cause the central bank to change its policy of targeting inflation during the period when assets prices are increase. After a bubble pops they argue that monetary should be expansionary to dampen the impact of declining asset prices on financial markets and the real economy.

A number of other researchers also support the asymmetric monetary policy response to asset bubbles hypothesis. Bullard and Schaling (2002) use a simple macroeconomic model to study the implications of targeting inflation, output and equity prices. They show that monetary policy that reacts to equity price increases can interfere with the policy maker's ability to minimize inflation and output variability. They also show that under certain conditions, a policy of targeting stock market prices can lead to an indeterminate rational expectations equilibrium and hence a more unpredictable volatility than would be achieved if asset prices were ignored. Bullard and Schaling (2002) conclude that targeting the stock market reduces the effectiveness of monetary policy relative to just concentrating on inflation and output gap targeting.

Similarly, Cogley (1999) argues that deliberate attempts to puncture asset price bubbles may destabilize the economy and thus monetary policy may generate instabilities that are similar to the ones arising from the burst of a bubble. Goodfriend (2003) is also skeptical about the effectiveness of monetary policy to target asset bubbles. He argues that the direction and size of the unconditional correlation between asset price movements and real short-term interest rates is not stable. Thus, in principle, the appropriate direction and size of the interest rate response to equity prices would be difficult to discern in practice. Bean (2003) carefully reviews several theoretical models to conclude that in a flexible inflation targeting framework it is very difficult to find an appropriate role for asset prices, other than their informational input to forecast of future inflation and growth.

Other researchers have argued for a symmetric monetary response to asset bubbles, that is, that central banks should increase interest rates in response to asset price bubbles, as well as cut interest rates when asset prices bubbles pop. A key assumption for a symmetric monetary response to asset bubbles to be optimal is that central banks can distinguish between a stock market bubble and a stock market boom caused by fundamentals.

Cecchetti (1998) and Cecchetti, et al (2000) are the initial papers that argue for a symmetric monetary response to asset bubbles. The logic behind this argument is the idea that the policymaker must often trade off variability in output for variability in prices because it is generally not possible to stabilize both. More specifically, Cecchetti, et al (2000), argue that central bankers can improve economic performance by paying attention to asset prices. Their conclusion follows from simulations of a New Keynesian macro model, similar to that used by Bernanke and Gertler (1999). The key difference from Bernanke and Gertler is that Cecchetti, et al 
(2000) assume that monetary policy makers know that an asset price bubble exists and also when it will pop. They also explore a larger family of policy reaction functions than the other authors. Continuing their support for the symmetric monetary policy response hypothesis, Cecchetti et al (2002) argue that there are sound theoretical reasons for monetary policy to improve the economy's performance by reacting to asset price misalignments as well as targeting inflation. They also emphasize that monetary policy reactions to stock price bubbles must be qualitatively different from reactions to stock price increases driven by fundamentals, such as increases in productivity and earnings. The concern with stock market bubbles is both their inevitable collapse but also the encouragement of over-investment and excessive borrowing by households and firms before the bubble collapse. Thus, bubbles can cause, both during their rapid growth and also after their collapse, serious economic imbalances that can cause either inflation or deflation.

Filardo (2001, 2004) also explores the role of monetary policy in an economy with asset bubbles by developing a small-scale macroeconomic model and running various simulations. He finds that if there is no uncertainty about the role of asset prices in determining output and inflation then monetary policy should respond to asset prices. However, if the monetary authority is sufficiently uncertain about the macroeconomic consequences of stock prices then it is preferable for monetary policy to remain neutral. Very recently, Disyatat (2005) has conceptualized the essential elements of the theoretical debate about of the central bank's appropriate response to bubbles and concludes that it is very difficult to resolve these issues analytically because the optimal control problem with a complicated loss function and nonlinear constraints does not allow for an explicit solution and only case by case simulations offer insights.

In addition to these two competing hypotheses, several economists have broadened the scope of the debate by considering the response of the central bank to macroeconomic conditions of financial fragility and financial instability rather than just asset bubbles. For example, Bordo and Jeanne (2002) argue that asset price reversals can be very costly in terms of declining output, such as the cases of the U.S. in the early 1930s or of Japan during the 1990s. They go further to argue that traditional monetary policy may be unable to correct such asset price disturbances and therefore monetary policy should attempt, primarily, to discourage the emergence and growth of bubbles, rather than act after they burst in an effort to stabilize the economy. Beyond stock market bubbles and inflation targeting, Borio and White (2004) broaden their discussion by emphasizing the notion of financial stability.

Blanchard (2000) argues that the analysis of Bernanke and Gertler (1999) is sufficient if asset inflation translates into price inflation via the wealth effect. Thus, if the bubble increases consumption, via the wealth effect, that puts pressure on inflation, and Fed tightening guided by inflation targeting can be optimal. However, allowing monetary policy to ignore asset price bubbles may be costly, if the bubble causes publicly traded firms whose equity has increased to increase their investment. 
In this case while inflation targeting keeps inflation constant, the stock market bubble results in a shift in the composition of output in favor of investment and thus potentially causes excessive capital accumulation. When ultimately the bubble bursts this excessive capital accumulation deters firms from investment and postpones economic growth. Thus inflation targeting does not address issues related to the impact of a bubble on the composition of output and the long-run impact of the bubble on capital accumulation and growth.

Therefore what is the answer to the normative question: should monetary policy react to an asset bubble? Clearly after the bubble bursts, monetary policy should always act in order to stabilize the economy. Both competing hypotheses agree that monetary policy should respond aggressively by lowering Fed funds after the collapse of the bubble. However, while the bubble is growing, it is difficult to argue what monetary policy should do because it is not clear how to identify a bubble and estimate its size. Also, it is not certain that a central bank can deflate slowly the bubble. A central bank, in its attempt to control the bubble may end up bursting it and thus cause financial instability that it wanted to prevent in the first place. Or, even worst, central bank may raise interest rates to slow down the bubble growth, and then observe that such increases accelerate the growth of the bubble as the Greenspan Fed witnessed in 1994.

\section{Assessing the risk and uncertainty faced by Fed in the 1990s}

To sum up the previous sections, from the mid 1990s to 2000, the stock market boomed. During this time where was an ongoing debate about the source of the boom: was it driven by a speculative mania and hence was it a bubble that would eventually burst, or was it driven by fundamentals? If the stock market boom was driven by fundamentals, then there was no need for the Fed to act to try to stop the boom. If the boom was being driven by a bubble then the Fed faced the choice of whether to tighten monetary policy to try to dampen or pop the bubble or to act asymmetrically and just respond after the stock market bubble eventually burst. Given the uncertainty about whether there was a bubble or not, and given the ambiguity about the appropriate monetary policy action and its consequences for the economy, the Fed chose to wait. After the bubble burst the Fed reduced interest rates to dampen the impact of the stock market collapse on the real economy. The next section discusses the political risks and uncertainties the Fed faced if it attempted to deflate the apparent stock market bubble.

\section{The political risk and uncertainty of acting against the stock market boom}

Even though the Fed is an independent government agency, it was created by an act of Congress in 1913. Monetary policy makers are well aware of this fact and know that if the policies they implement are sufficiently unpopular politically they face will political pressure from Congress and the President and potential change in the institutional structure of the Fed. Hence without at least implicit political consensus and support from Congress and the President, the Fed will not undertake what might 
be considered radical changes in the monetary policy. While the idea that Congress would change the institutional structure of the Fed, for example making it part of the U.S. Treasury, might be considered a very low probability event, as Greenspan states, in a risk-uncertainty management framework, low probability events that would result in large losses have to be insured against.

To see the role that politics has played in the setting of monetary policy, consider the "great inflation" in the United States. From 1965 to 1979 the trend rate of inflation accelerated. It took fifteen years of accelerating inflation for a political consensus to develop to disinflate the economy via a recession (see DeLong (1997)). After a false start in October 1979, the Fed tighten monetary policy from November 1980 to August of 1982 resulting in the deepest recession in the US since the Great Depression. The 1981-82 recession was successful in lowering the trend rate of inflation down to the 2 to $4 \%$ range. Mussa (1994) suggests that use of targeting monetary aggregates during this period was partly politically motivated in attempt to diffuse the responsibility for higher interest rates away from the Fed. In addition, Mussa argues that the timing of the second tightening of monetary policy in November 1980, right after the Presidential election and the abandoning of the use of monetary aggregate targets in August 1982, three months before the mid-term elections was also politically motivated. In the twenty years since the Fed has been successful in maintaining low inflation. Alan Greenspan (2004) attributes the low inflation since the mid 1980s in part to the political support for low inflation.

Clearly goods price inflation is politically unpopular. However no such public consensus existed for monetary policy to try to pop the stock market bubble of the 1990s. In fact, at the time the investing public seemed to enjoy the stock price inflation. In addition as discussed above, during the 1990s there was no consensus among economists that a bubble did exist. It seems conceivable that if the Fed had decided to increase the Federal funds rate solely for the reason of trying to stop the stock market boom that this act would have been very politically unpopular and much more difficult to defend than raising interest rates to stop goods price inflation. Hence increasing interest rates to pop the bubble would have increased the probability, however low it might be, of a loss of institutional independence of the Fed. Given that this event would cause a large loss for the Federal Reserve System as an institution, and also potentially to society at large. Research suggests that a loss of central bank independence may result in higher trend goods price inflation. Thus, political risks and uncertainty, offer an additional reason for the Fed taking no action to deflate the bubble.

\section{Conclusion}

The Fed faced considerable risk and uncertainty in selecting the appropriate response of monetary policy to the stock market boom of the 1990s. As the boom continued in the late 1990s, the Fed as well as everyone else was uncertain whether the boom was

driven by fundamentals or irrational speculation. If the boom was a bubble, the Fed faced the policy choice of either attempting to pop the bubble by raising interest rates 
or remaining neutral with respect to the stock market. This paper suggests that risk of attempting to pop were both economic and political. Increasing interest rates dramatically enough to stop the stock market boom would have likely caused a significant slowdown in the economy. Given the lack of political support for a preemptive move against the stock market, the political risks to the Fed for such a move were high. In the end, in the midst of the uncertainty about the bubbles' existence and size and in view of the risks to the real economy of a monetary tightening, the Fed chose an asymmetric respond to stock prices. That is, a neutral monetary policy while the stock market was booming and a dramatic cut in interest rates after the stock market bust appeared to be threatening real economic activity. 


\section{Notes}

1. Marc D. Hayford is Associate Professor of Economics at Loyola University Chicago. A. G Malliaris is the Walter F. Mullady, Sr. Professor of Economics and Finance at Loyola University Chicago.

\section{References}

Bean C., (2003) “Asset Prices, Financial Imbalances and Monetary Policy: Are Inflation Targets Enough?”, BIS Working Papers, no 140.

Bernanke B. (2002), “Asset Price ‘Bubbles’ and Monetary Policy” speech before the New York Chapter of the National Association for Business Economics.

Bernanke B. and M. Gertler (1999), "Monetary Policy and Asset Price Volatility”, Federal Reserve Bank of Kansas City Economic Review, pp 17-51.

Bernanke B. and M. Gertler (2001), “Should Central Banks Respond to Movements in Asset Prices?” American Economic Review, Vol. 91, No. 2, pp. 253-57.

Blanchard O. (2000), "Bubbles, Liquidity Traps and Monetary Policy”, in A. Posen and R. Mikitani (eds), Japan's Financial Crisis, Washington DC: International Institute of Economics.

Bordo M. and O. Jeanne (2002), "Monetary Policy and Asset Prices: Does 'Benign Neglect’ Make Sense?” International Finance, Vol.5, No. 2, pp. 139-164.

Bordo, M. and D. Wheelock (2004), "Monetary Policy and Asset Prices: A Look Back at Past U.S. Stock Market Booms”, Federal Reserve Bank of St. Louis Review, 86, pp.19-44.

Borio C. and W. White (2004), "Whither Monetary and Financial Stability? The Implications of Evolving Policy Regimes”, BIS Working Paper, No 147.

Bullard, J. and E. Schaling (2002), "Why the Fed Should Ignore the Stock Market", Federal Reserve Bank of St. Louis Review, 84, pp.35-41.

Cecchetti, S. (1998), "Policy Rules and Targets Framing the Central Bank's Problem”, Economic Policy Review of the Federal Reserve Bank of New York, pp. 1-18.

Cecchetti S., Genberg H., Lipsky J. and Wadhwani (2000), Asset Prices and Monetary Policy, London: International Centre for Monetary and Banking Studies.

Cecchetti, Stephen and Hans Genberg and Sushil Wadhwani (2002) “Asset prices in a flexible inflation targeting framework” in William Hunter, George Kaufman and Michael Pomerleano edited Asset Price Bubbles: The Implications for Monetary, Regulatory and International Policies The MIT Press.

Cogley T. (1999), "Should the Fed Take Deliberate Steps to Deflate Asset Price Bubbles?” Economic Review of the Federal Reserve Bank of San Francisco, pp.42-52.

DeLong, B. (1997) "Peacetime Inflation of the 1970s" in Romer, C. and Romer, D. ed, Reducing Inflation: Motivation and Strategy University of Chicago Press p247-280 
Disyatat, P. (2005), "Inflation Targetin, Asset Pricesand Financial Imbalances: Conceptualizing the Debate:, BIS Working Paper No 168.

Ferguson, Jr R. W. (2004) “Equilibrium Real Interest Rate: Theory and Application” speech given by FRB Vice Chairman Ferguson to the University of Connecticut School of Business Graduate Learning Center and the SS\&C Technologies Financial Accelerator, Hartford, Connecticut, October, 29.

Filardo A. (2000), "Monetary Policy and Asset Prices" Federal Reserve Bank of Kansas City Review, 85, pp.11-37.

Filardo A. (2001), "Should Monetary Policy Respond to Asset Price Bubbles? Some Experimental Results”, in G. Kaufman (ed.), Asset Price Bubbles: Implications form Monetary and Regulatory Policies, Elsevier Science: Amsterdam.

Filardo A. (2004), "Monetary Policy and Asset Price Bubbles: Calibrating the Monetary Policy Tradeoffs", BIS Working Paper, No.155.

Greenspan A. (1999), comments on p. 143 in "General Discussion: Monetary Policy and Asset Price Volatility" in New Challenges for Monetary Policy A symposium sponsored by the Federal Reserve Bank of Kansas CityJackson Hole, Wyoming August 26-28, 1999

Greenspan A. (2002), “Opening Remarks” Rethinking Stabilization Policy A symposium sponsored by the Federal Reserve Bank of Kansas City Jackson Hole, Wyoming August 29 - 31, 2002

Greenspan A. (2003) "Opening Remarks" in Monetary Policy and Uncertainty: Adapting to a Changing Economy A symposium sponsored by the Federal Reserve Bank of Kansas City Jackson Hole, Wyoming August 28 - 30, 2003

Greenspan A. (2004), "Risk and Uncertainty in Monetary policy”, Remarks by Chairman Alan Greenspan at the Meetings of the American Economic Association, San Diego, California, January 3, 2004.

Goodfriend M. (2003), "Interest Rate Policy Should Not React Directly to Asset Prices”, in Hunter W., G. Kaufman and M. Pomerleano eds., Asset Price Bubbles: The Implications for Monetary, Regulatory, and International Policies, Cambridge: MIT Press.

Hayford, M. and A. Malliaris (2001), "Is the Federal Reserve Stock Market Neutral?” in G. Kaufman (editor) Asset Price Bubbles: Implications for Monetary Policy and Regulatory Policies, New York: JAI Press, pp. 229-43.

Hayford M. and A. Malliaris (2004a), "Monetary Policy and the U.S. Stock Market", Economic Inquiry, Vol. 42, pp. 387-401.

Hayford M. and A. Malliaris (2004b), "Rethinking Monetary Policy in the Presence of a Bubble: Should the Response be Asymmetric?“, paper presented at the Sixth Athenian Policy Forum-Bundesbank Global Conference, July 28-31, 2004, Frankfurt, Germany.

Hayford M. and A. Malliaris (2005), "How did the Fed React to the 1990s Stock Market Bubble? Evidence from an Extended Taylor Rule”, European Journal of Operational Research, 163, pp. 20-29. 
Kindleberger, Charles, (1989), Manias, Panics and Crashes, Basic Books

Mussa, M (1994) “U.S. Monetary Policy in the 1980s" in Feldstein, M. edited American Economic Policy in the 1980s University of Chicago Press, 1994

Salge M. (1997), Rational Bubbles. New York: Springer.

Shiller R. (1989), Market Volatility, Cambridge, MA: MIT Press.

Svensson L. (2003), "What Is Wrong with Taylor Rules? Using Judgment in Monetary Policy through Targeting Rules", Journal of Economic Literature, Vol.41, pp. 203-246.

Woodford, M. (2003), Interest and Prices: Foundations of a Theory of Monetary Policy, Princeton University Press 
Figure 1
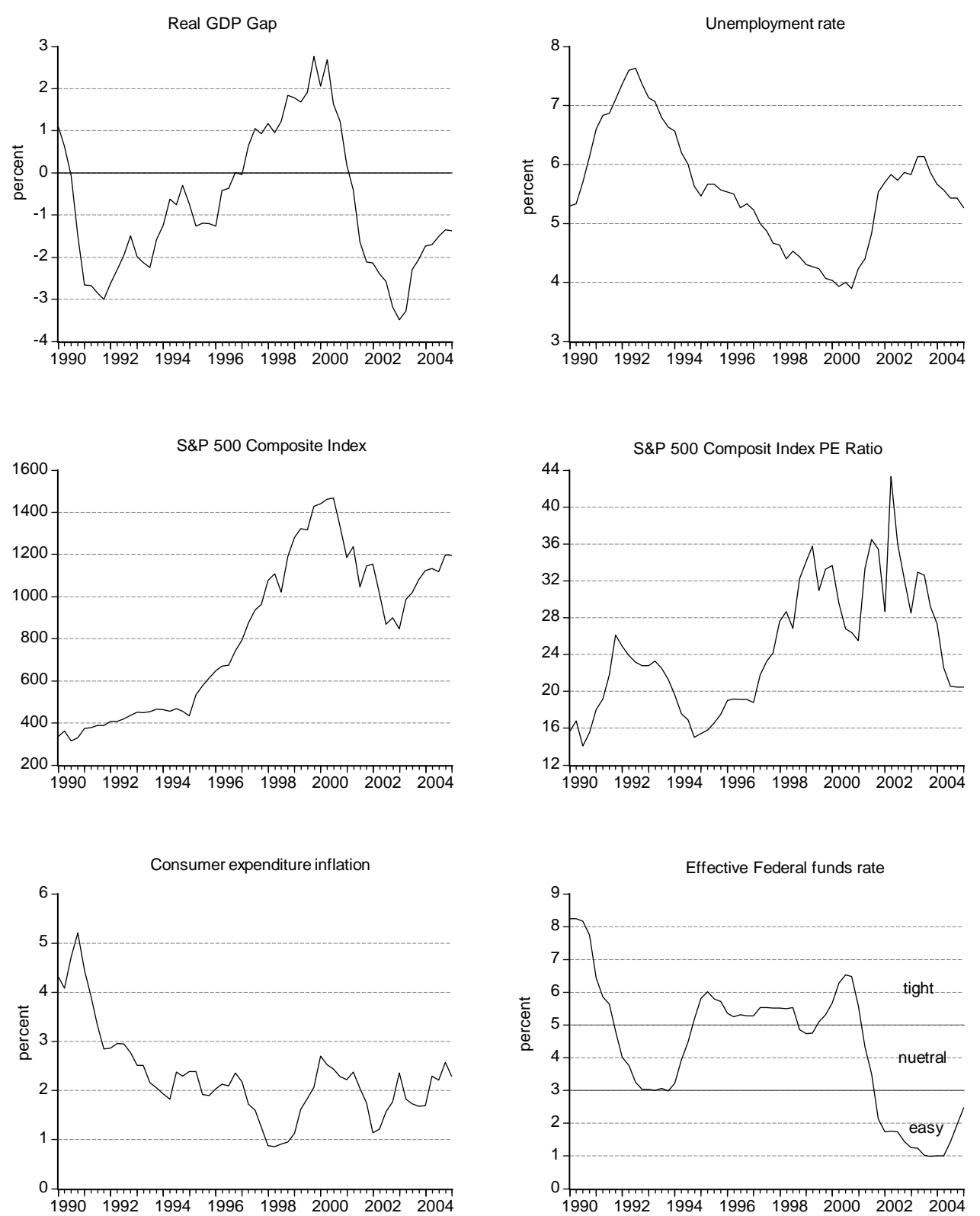